\title{
No sé qué day: Code-switching and code-mixing in a plurilingual family living in Catalonia
}

\author{
Jill Simon Auerbach \\ Universitat Autònoma de Barcelona, Barcelona, Spain
}

(Article received 29 September 2011; Final version received 13 November 2011)

This study analyzes the unique plurilingual (Catalan, Spanish and English) speech of a family living in Catalonia in order to understand the variety of forms in which linguistic multicompetence is made manifest in their dialogues. Factors that were found to influence code-switching and code-mixing in dialogues among family members include: the context of the conversation, the expression of distinct discursive voices, the affective consequences of employing the dominant or non-dominant language of the interlocutor, the ingrained nature of discourse markers, resistance to changing the names of academic concepts or courses, and the desire to creatively combine elements of distinct language systems to suit the expressive needs of the speaker. An argument is made in favor of a distinction being made between linguistic variety and communicative code as well as for a user-based, pragmatic view of language knowledge.

\section{Introduction}

Over the past decade, our understanding of plurilingual speech has undergone important changes. Plurilinguistic individuals possess a linguistic repertoire that goes beyond the mere addition of monolingual systems. Rather, they possess resources that form part of an open set of grammatical, syntactic and gestural microsystems that can be used freely to create previously unheard utterances or to reinforce others (Lüdi \& Py, 2009). Recent theories point to the 'multicompetence' (Cook, 1991, 2003) of plurilingual speakers who use their linguistic choices to enrich their speech in a variety of creative ways that are not available to monolingual speakers.

Recognizing that plurilingual competence is an ability distinct from that which allows a speaker to communicate in any one specific language system is a first step in describing this multicompetence. Alvarez-Cáccamo (1998) argues against considering the linguistic and communicative codes as one and the same. A plurilingual speaker 
may alternate the speech code in order to maintain the communicative code. Alternatively, a switch in the communicative code may occur in the context of monolingual speech (ibid). Hall, Cheng and Carlson (2006) argue that the pragmatic form in which speakers activate and use their entire repertoire of grammatical and linguistic knowledge is situationally-determined and dependent upon the interlocutors in a conversation.

The family is a locus of plurilingual activity in which first generation immigrants and their children interact in their native, heritage or acquired languages, often switching back and forth between one and another (Unamuno \& Nussbaum, 2006). This study looks at the translinguistic markers in the speech of three plurilingual children living in the bilingual (Spanish-Catalan) province of Barcelona, Spain as they converse with their American-born mother in order to identify and analyze the different forms in which linguistic multicompetence enriches their dialogues.

\section{Conceptual Framework}

\section{Code-switching and code-mixing}

As our developing knowledge of plurilingual speech changes, so too does our understanding of translinguistic markers. Code-switching is defined as the alternating use of languages between utterances, whereas code-mixing is the use of more than one language in an utterance or the formation of hybrid forms ( $\mathrm{Li}, 2000)$. Both codeswitching and code-mixing play an important role in maintaining or disrupting the interlocutive space and the interactional character of a communicative exchange (Goffman, 1974, 1981).

For many years, code-switching and mixing were considered to be the inevitable negative consequence of learning a second language. This undesirable form of speech, known as an interlanguage (Selinker, 1972), was an unfortunate stage through which learners had to pass on their way to native-level communicative competence. Weinreich (1953) labeled these unwelcome intrusions as interferences - a "deviation from the norms of either language” (p.1).

In recent years, a more positive view of the use of code-switching and codemixing within the realm of bilingual and plurilingual speech has developed (Lüdi \& Py, 2009). In this view, translinguistic marks are considered to be the expression of a 
plurilingual speaker's choice in a given pragmatic and motivational context. When an individual chooses to code-switch, he is offering a contextualization cue (Gumperz, 1982) to a change in the social or situational orientation of his discourse. Li (2000) describes how discourse-related switches indexed to motivational or situational circumstances (Auer, 1984, 1998) are a characteristic feature of bilingual speech. The function of a code-switch or code-mix in the speech of plurilinguals serves a variety of communicative purposes: to emphasis a certain aspect of their speech, to employ a word with a nuance unavailable in the alternative language, to maintain or interrupt the course of a conversation, to add a humoristic element to the conversation, to establish distance or intimacy with the fellow interlocutor (Lüdi \& Py, 2009) or to respond with language-specific, ‘discursive voices’ to particular situations (Woolard, 1988).

Alternating use of language in discourse has been systematically associated with specific social and discursive meanings attached to each speech variety (AlvarezCáccamo, 1998, 1990). Alvarez-Cáccamo (1998) focuses on the original meaning of code as a "system of transduction between two sets of signals" (p.30) to argue that the notions of communicative code and linguistic variety are distinct. Communicative codeswitching may occur in what is formerly recognized as monolingual speech and a switch in the linguistic variety may be used to maintain the communicative code. (Alvarez-Cáccamo, 1990, 1998).

\section{Multicompetence}

Cook (1991) first used the term 'multicompetence' in order to develop an adequate theory of linguistic knowledge that took into account the language knowledge of multilinguals. As opposed to the idealized monolingual speaker described in Chromsky’s (1965) theory, Cook (1991, 2003) argued that multiple grammar systems are the norm among individuals, not the exception. As opposed to monolingual speakers, plurilingual individuals possess multilingual competencies (ibid) that go above and beyond the sum of the individual linguistic varieties a speaker may know. In this view, L2 users are considered to be "successful multicompetent speakers" (Cook 1999, p. 204).

Lüdi and Py (2009) describe the situated manner in which numerous varieties of speech are used simultaneously in "flexible and efficient ways" (p. 163) as "speaking 
plurilingually" (p.161). In this type of speech, the entire repertoire of the 'bilingual mode' is activated and negotiated between the interlocutors (Grosjean, 1985). Plurilingual speech is marked by a great number of translinguistic marks with many changes between the matrix and embedded language (Myers-Scotton, 1997).

While the concept of multicompetence has positively recast the light in which plurilingual speakers are viewed, it is not yet clear how this competence is acquired or in what manner it functions. According to Hall, Cheng and Carlson (2006), most researchers consider that monolingual and multilingual competences represent two distinct systems- the former finite and stable, the latter dynamic and variable. These authors argue, in contrast, that there is compelling evidence for a user-based view of language knowledge. Rather than comprising stable components of an a-contextual system, grammatical and linguistic elements emerge in the course of an interlocutor's pursuit of a pragmatic aim. Knowledge of language, thereby, varies according to its situational use (ibid).

\section{Objective}

The aim of this study is to identify and describe code-switching and code-mixing in the dialogues of three plurilingual children with their mother in order to understand how they use their plurilingual multicompetence to enrich their communicative exchanges and in what way this alternation of speech is situated pragmatically. This enrichment may take the form of emphasis, humor, whim, maintaining or interrupting the interaction, establishing intimacy or distance (Lüdi \& Py, 2009), or adapting distinct discursive voices (Woolard, 1988).

\section{Context and Object of the Study}

The data of this study were collected in the home of a middle-class family living in a suburb of Barcelona. The family is comprised of five members: the mother, a native American who lived in the United States for twenty years before coming to Catalonia eighteen years ago; the father, a Spaniard originally from Leon, Spain who migrated to Catalonia with his family as a teenager; a ninteen-year old daughter, Lisa, a seventeen- 
year old son, Karl, and a thirteen-year old son, Oriol. The focus of the study is on the children's speech.

The multicompetence of the children in Spanish, Catalan and English is a consequence of their simultaneous language exposure to Spanish and English in the home, and to Catalan and Spanish in the social setting and at school. All the children have grown up and attended the school system in Catalonia. The home environment has provided them with simultaneous exposure to Spanish, on behalf of the father, and English, on behalf of the mother. Results will show the predominant use of each of these languages by the parents.

Apart from the English exposure in the home, the children have had between three (Oriol) and ten (Lisa and Karl) hours a week of formal English instruction during primary school. Lisa's overall competence in English has been certified by a TOEFL score of 118/120 points in June 2011.

Although the mother's speech is not analyzed, it is important to establish her linguistic competence in the languages under consideration as an active participant in the conversations. The mother's fluency in English is a result of her growing up in the United States in an English-speaking household. English, therefore, is her dominant language. Her level of Catalan has been certified as proficient (C2 CEFR) on an official exam offered by the Catalan administration in 2003. Her Spanish level was also found to be proficient in a qualifying exam in 2002 for her job as a schoolteacher.

\section{Data Collection and Analysis}

The data of this study consist of six audio clips ranging from three to sixteen minutes with, approximately, a total running time of fifty minutes. The data were collected under naturalistic conditions and represent one-to-one conversations between the mother with Lisa or Karl, with the exception of a brief conversation among all three children with some minimal interventions by the mother. All the recordings were made in June 2011 except for the children’s conversation, which was made in February 2011.

The data were screened to identify sequences of further interest for analysis, and the identified sequences were transcribed following the transcription format of the GREIP research group. Color-coding has been added in certain transcripts to highlight the use of Spanish, Catalan or English in the speech of the children (see Annex 1). 
Language choice preferences between family members were determined by a log kept by the investigator indicating the language in which family members first addressed each other (excluding greetings) when beginning a new interaction. Entries in the log were made until each member had addressed each of the other members a total of twenty-five times and the data were tabulated. Language choice in the transcribed sequences was analyzed quantitatively to determine the word count and percentage of speech in a particular language by a given member.

Discourse analysis in search of translinguistic marks in the children's speech was used to analyze the text in a pragmatic approach, i.e. any information considered pertinent to the analysis, such as details of the context or comments by the participants on hearing the recordings has been included.

\section{Results and Analysis}

Language preferences between family members

Tables 1 and 2 show the language used by the father or the mother (Table 1) or the children (Table 2) to address each of the other family members on twenty-five separate occasions. Greetings were excluded due to their ingrained nature in the speech of all the participants. The results of the tabulation illustrate the bilingual environment in the house and serve to establish the preferred language of each family member with each other. 
Table 1. Languages used by father and mother

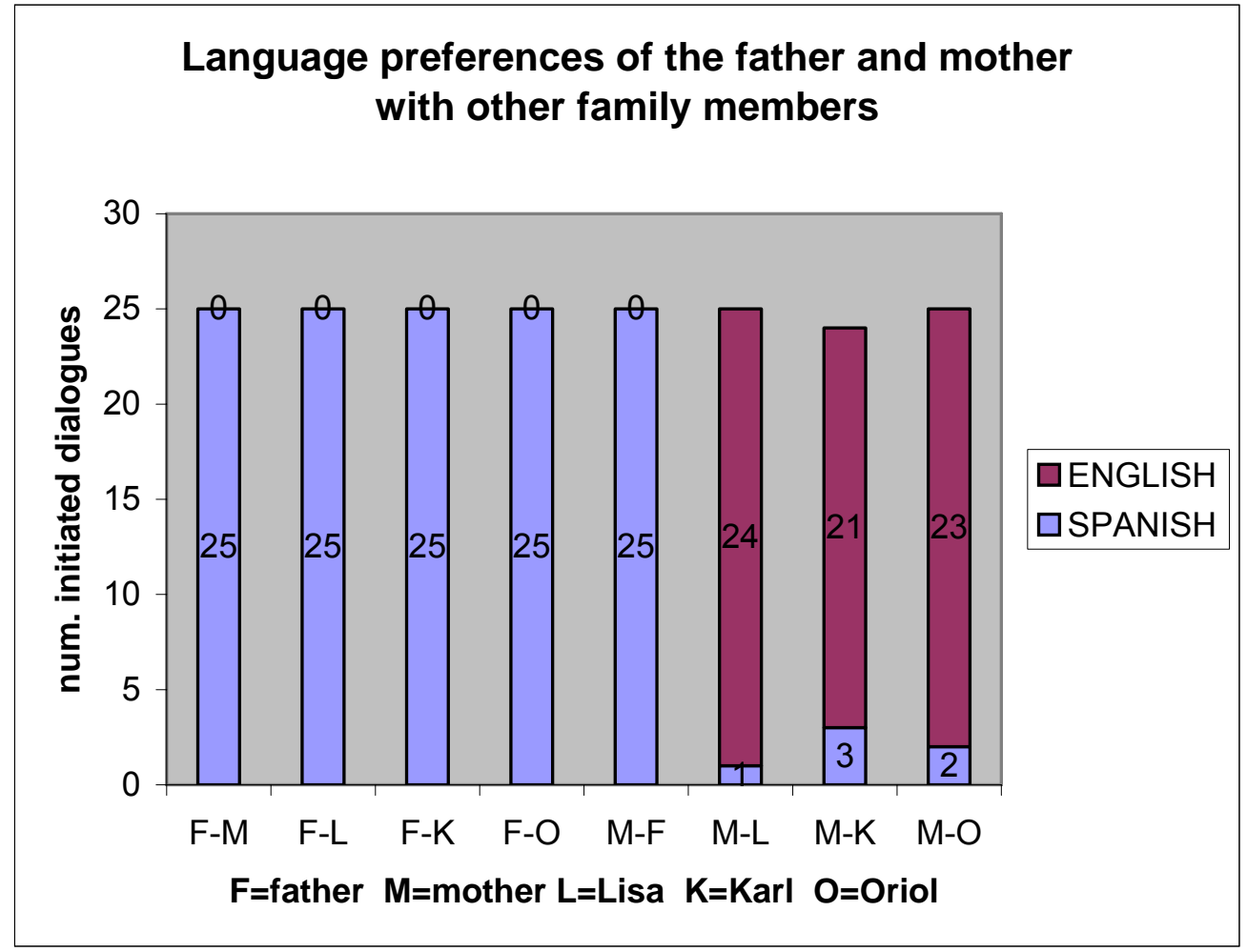

In this table, we can see that the father speaks exclusively in Spanish in his interactions with all other family members (F-M, F-L, F-K, F-O). The mother speaks exclusively in Spanish to the father (M-F), while her preferred, though not exclusive, language with her children is English (M-L, M-K, M-O).

Table 2. Languages used by children

\section{Language preferences of Lisa, Karl and Oriol with other family members}

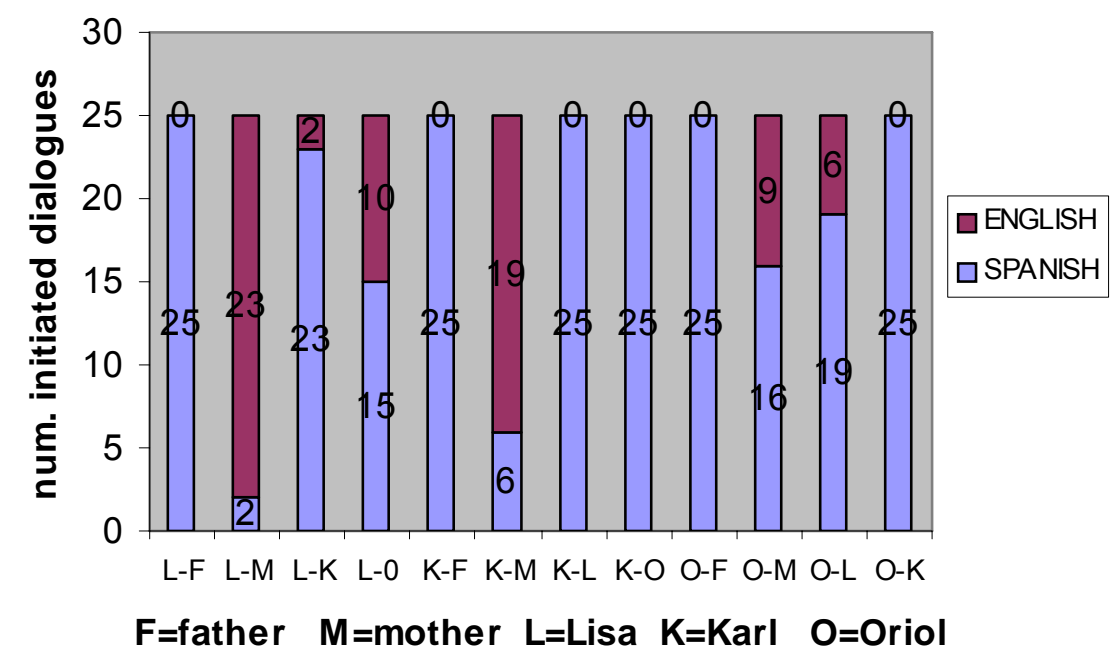


An analysis of Table 2 shows that all three children speak exclusively in Spanish to their father. Lisa shows a clear preference for speaking English with her mother (L-M) whereas with Karl (L-K). She prefers to speak Spanish. Her language choice with Oriol (L-O) is unstable although she appears to prefer Spanish to a small degree. Karl's preferred language with his mother (K-M) is English. He speaks exclusively in Spanish to his brother (K-O) and sister (K-L). Oriol speaks exclusively in Spanish with Karl (O$\mathrm{K})$. Oriol's preferred language with his mother $(\mathrm{O}-\mathrm{M})$ or sister $(\mathrm{O}-\mathrm{L})$ is Spanish, although he speaks in English on many occasions.

\section{Language use in the transcribed conversations}

Table 3. Language in transcriptions

\begin{tabular}{|c|c|c|c|c|c|c|}
\hline & \multicolumn{6}{|c|}{ Language use of family members in transcribed conversations with their mother } \\
\hline & $\begin{array}{c}\text { Transcription } \\
\text { name }\end{array}$ & Word count & \% Eng & \% Span & $\%$ Cat & \% mixed \\
\hline \multirow{6}{*}{ Mami } & kitchon & 307 & 99\% & $<1 \%$ & 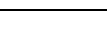 & 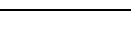 \\
\hline & where to study & 66 & $100 \%$ & - & - & - \\
\hline & time warp & 29 & $100 \%$ & - & - & - \\
\hline & Entrance exam & 198 & $97 \%$ & $3 \%$ & - & - \\
\hline & university & 528 & $88 \%$ & $9 \%$ & $3 \%$ & - \\
\hline & $\begin{array}{l}\text { *Mami trying that } \\
\text { I speak }\end{array}$ & 41 & $100 \%$ & - & - & - \\
\hline & & & & & & \\
\hline \multirow{4}{*}{ Lisa } & kitchen & 418 & $82 \%$ & $18 \%$ & - & - \\
\hline & where to study & 349 & $90 \%$ & $10 \%$ & - & - \\
\hline & time warp & 48 & $75 \%$ & $25 \%$ & & - \\
\hline & $\begin{array}{l}* \text { Mami trying that } \\
\text { I speak }\end{array}$ & 118 & $91 \%$ & $9 \%$ & - & $<1 \%$ \\
\hline & & & & & & \\
\hline \multirow{3}{*}{ Karl } & Entrance exam & 122 & $68 \%$ & $32 \%$ & - & - \\
\hline & university & 195 & $13 \%$ & $81 \%$ & $6 \%$ & - \\
\hline & $\begin{array}{l}* \text { Mami trying that } \\
\text { I speak }\end{array}$ & 23 & - & $90 \%$ & $10 \%$ & - \\
\hline & & & & & & \\
\hline Oriol & $\begin{array}{l}\text { *Mami trying that } \\
\text { I speak }\end{array}$ & 42 & $67 \%$ & $33 \%$ & $<1 \%$ & $<1 \%$ \\
\hline
\end{tabular}

The quantitative analysis of language use in the transcripts shows that the mother normally addresses her children in English (88\%-100\%). Lisa usually uses English with her mother as well (75\% -91\%). When considering Lisa's speech with her mother, it is important to bear in mind her excellent result on the TOEFL exam which indicates that she is more than capable of producing academically-correct English when required. 
Karl, on the other hand, shows a wide variance (13\% and 68\%) in his English speech in the two principle conversations that are analyzed with his mother. Given that Karl's preferred language with his mother is English (Table 2), the analysis will attempt to explain the contextual and situational reasons behind Karl's low use of English in the transcript named 'university' (Extract 3). The word count of Oriol is too small to draw any important conclusions.

Code-mixing and code-switching in the children's conversations with their mother: Extracts 1 and 2

In Extract 1, Karl and his mother are discussing his preparation for an entrance exam to attend university. In the first part of the conversation (turns 1-3), Karl explains how his preparation for the Spanish exam is progressing. Karl's mother then enquires about his progress in two other classes (turns 4-8). Between turns 9-27, the conversation revolves around what exams Karl must take and on what days. Karl's answers in these turns (10, 12, 16, 18, 20, 22, 24 and 26) are limited to numbers or lists of classes, with the exception of turn 20 in which Karl uses a sentence to help him organize the list of classes he is naming. Finally, in turn 28, Karl interrupts the line of the conversation to express his doubts about how to get to the exam site.

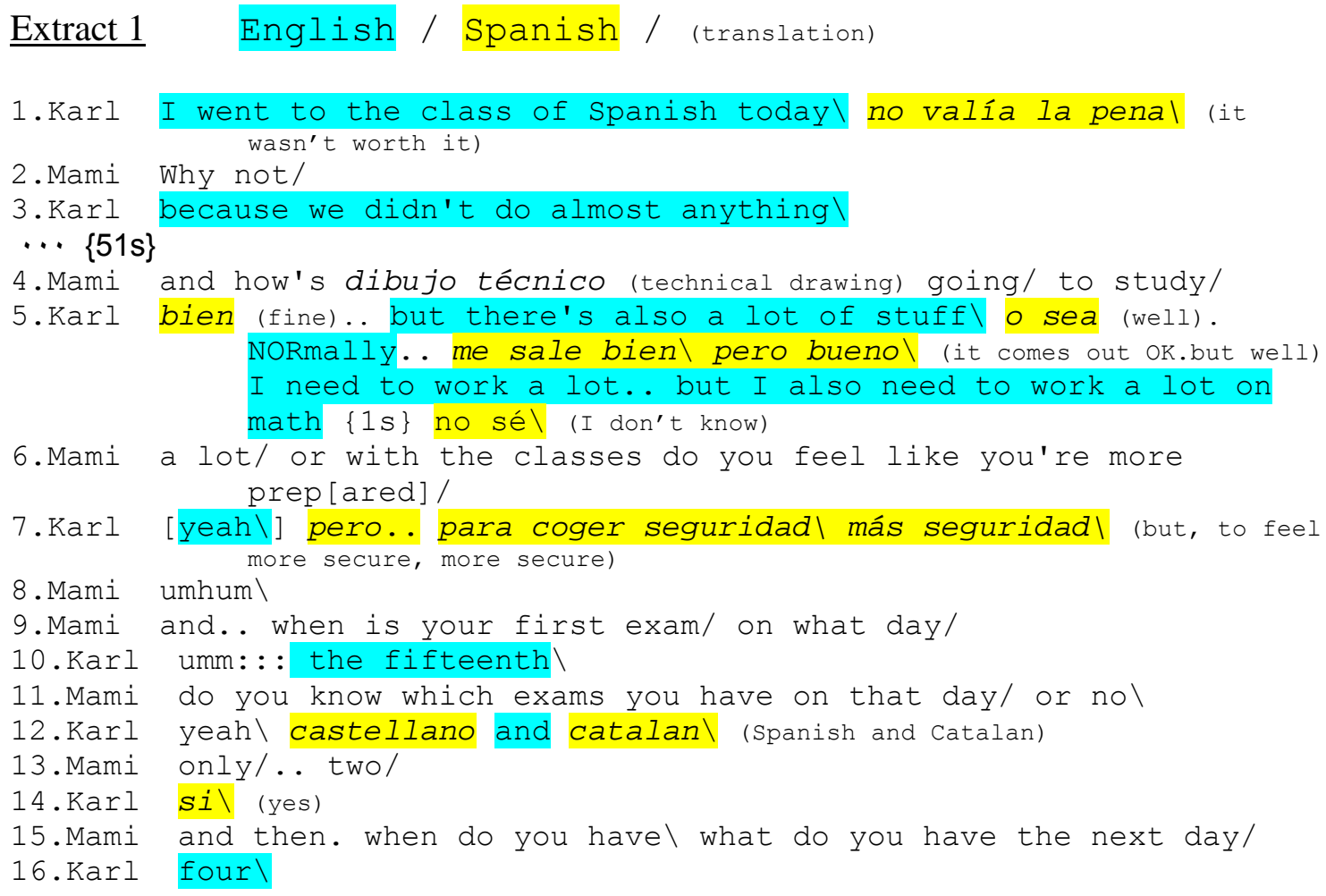




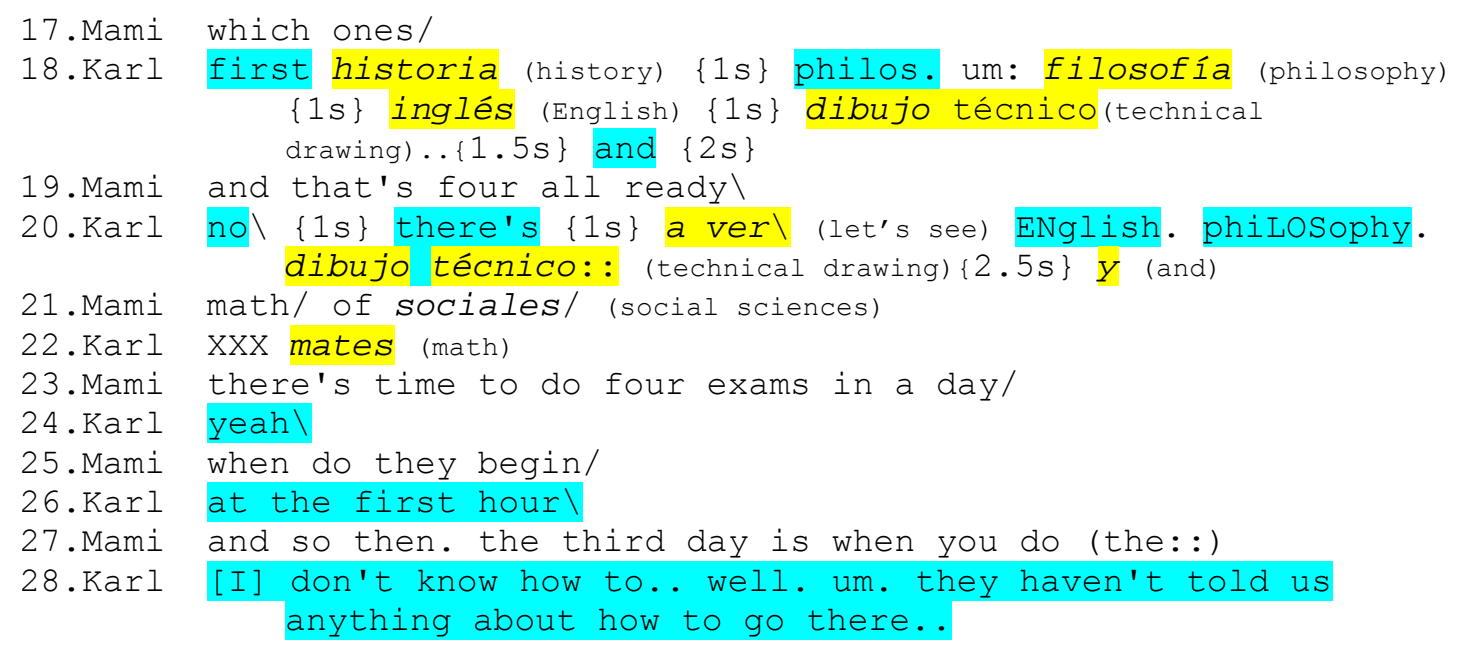

In this dialogue, 68\% of Karl's utterances are in English and the remaining 32\% are in Spanish. The majority of complete sentences that he uses to state facts (turn 1), express opinions (turns 3 and 5), or consult doubts (turn 28) are in English, as is the connecting word 'and' in turn 12 and 18. Karl's base or 'matrix' language (Myers-Scotton, 1997) in this conversation would appear, then, to be English. We must also bear in mind that Karl's preferred language choice with his mother is English (see Table 2). Spanish is employed in a number of forms within this general frame: as a discourse marker ("o sea”, ”no sé”, ”pero,” “bueno”, ”a ver”); as the name of a class (“castellano”, “catalan”, "historia”, etc.); as well-established Spanish speech units or expressions ("no valia la pena”, “me sale bien”,); or as simple word utterances (“bien”, “si”).

The code-switching in the utterances of "no valía la pena”, "me sale bien” and “para coger seguridad, más seguridad” (turns 1, 5 and 7, respectively) could be related to many factors- maintaining the frame of the conversation despite an incomplete knowledge of the English equivalent; an impression that these words more clearly expressed Karl's communicative intention than their English translations; a change of footing to that of a fellow student commenting on the worthiness of a class; or merely the prerogative of any bilingual speaker in a conversation with an equally bilingual interlocutor to choose and use his language repertoire as he sees fit (Lüdi \& Py, 2009).

Lastly, Karl's naming of the subjects on the exam is produced mostly, but not entirely in Spanish. In turn 18, Karl makes an effort to remember which subjects are examined on the same day. Given the similarity of Spanish and Catalan, and the fact that Karl studies these classes in Catalan, it is possible that this list is more readily available in Spanish than in English 
In turn 20 Karl renames the first two exams in English, putting an added emphasis on the accented syllable, as if he is ticking them off in his head. Perhaps stating them in English separates them from previously identified examinable subjects. In any case, the following class, “dibujo técnico,” is named in Spanish. The English translation of this term is not so simple as philosophy-filosofía or English-inglés. In fact, according to Karl and his mother, Karl has only ever referred to this class in Catalan or in Spanish and his mother does so in the same way, as manifest in turn 4. This form of maintaining the name of a class or concept in the language in which it is learned, or in a very similar language (Spanish-Catalan) is common in the speech of all the children as well as their mother.

In Extract 2, Karl is talking with his brother about an excellent exam result. In a turn whose matrix language is clearly Spanish, Karl uses Catalan to describe the content of the exam as “moviment rectilini” ('straight-line motion'), an academic concept studied exclusively in the school context and through the medium of Catalan.

\section{Extract 2 English /Spanish / Catalan / uncertain /(translation) \\ Karl Que no te gusta sacar un diez/ Qué te \\ pasa/ (You don't like getting a ten?)\{laughing\}Ah... \\ Era de moviment rectilini/ (It was on straight line motion/) [Lo que te hizo de los pueblos y esol (what I asked you about the towns and stuff)}

In an unrecorded conversation about the topic of naming classes, Lisa commented that using the Spanish name of a course in an English-based conversation “didn’t count” as changing languages, demonstrating just how internalized the use of certain contextassociated terms can be. Furthermore, Lisa claimed that she would have to "think about it” if forced to use an English term when speaking with her monolingual American grandfather. Lisa's effort to reconfigure a locally learned construct in English supports Alvarez-Cáccamo’s (1998) suggestion that communicative code-switching can also occur in same system speech.

[...] if a communicative code is something systematically associated with activities, identities and interactional meanings, and if at times two or more varieties may carry comparable meanings, why not then speak of 'switches' only at points where activities change or local identities are reconfigured in spite of a single language variety being used ( p. 38) 
Code-mixing and code-switching in the children's conversations with their mother: Extracts 3, 4, 5 and 6

In Extract 3, Karl and his mother are seated in front of the computer as they consult both Internet and printed material related to the choice of university programs. In turn 1, Karl's mother suggests that they look at the information about these programs together. In the following turn, Karl protests that they had already consulted this information the previous day, to which his mother insists on looking at it again. Between turns 7 and 26, Karl and his mother discuss specific programs and Karl's frustration grows as his mother insists on considering a program in which he has no interest. In the last section, Karl's mother explains her reasons for trying to find more possible university choices to Karl, who, in turns 34 and 36, indicates that he has found one that could be acceptable.

\section{Extract 3 English / Spanish / Catalan/ uncertain /(translation)}

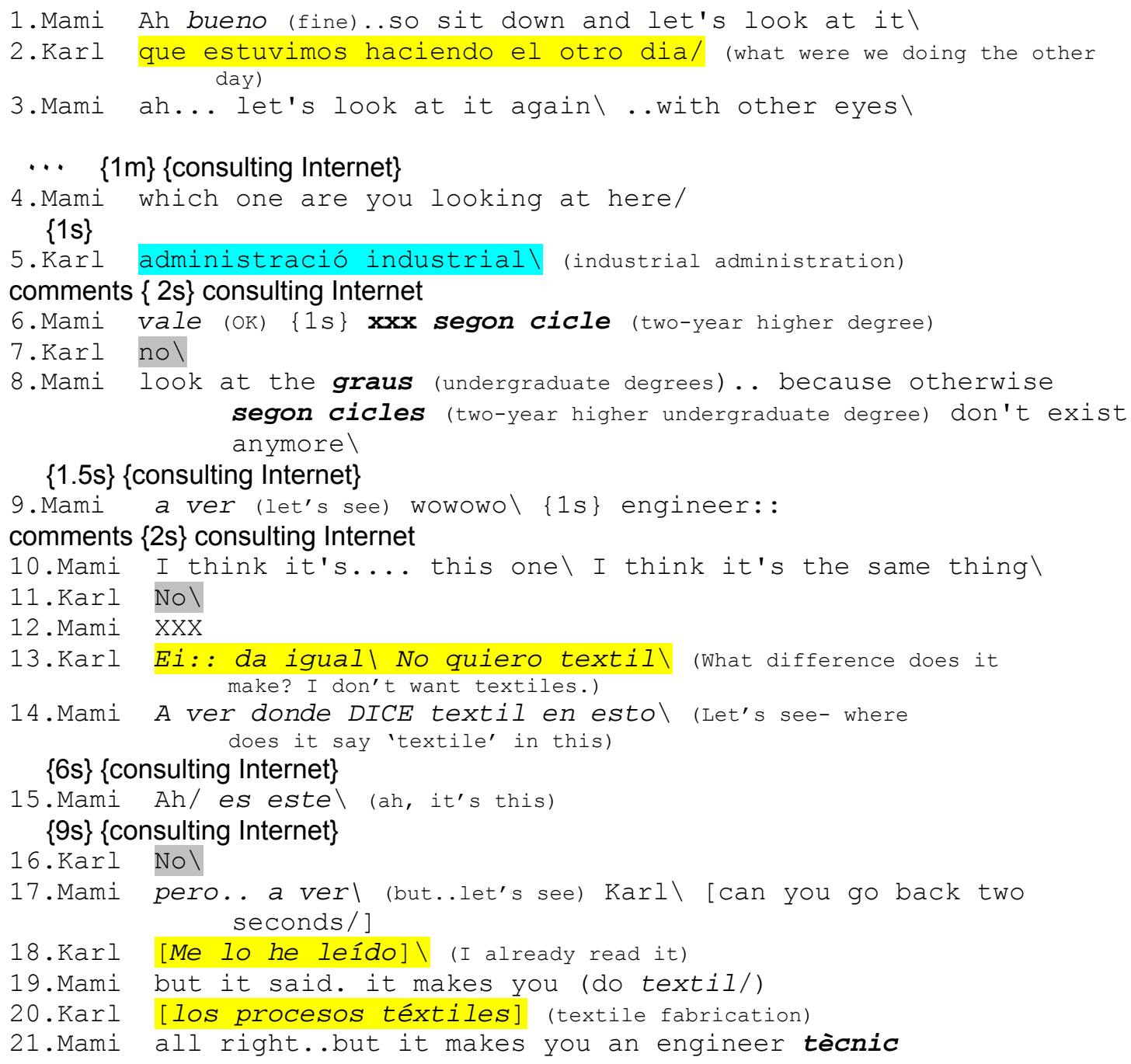




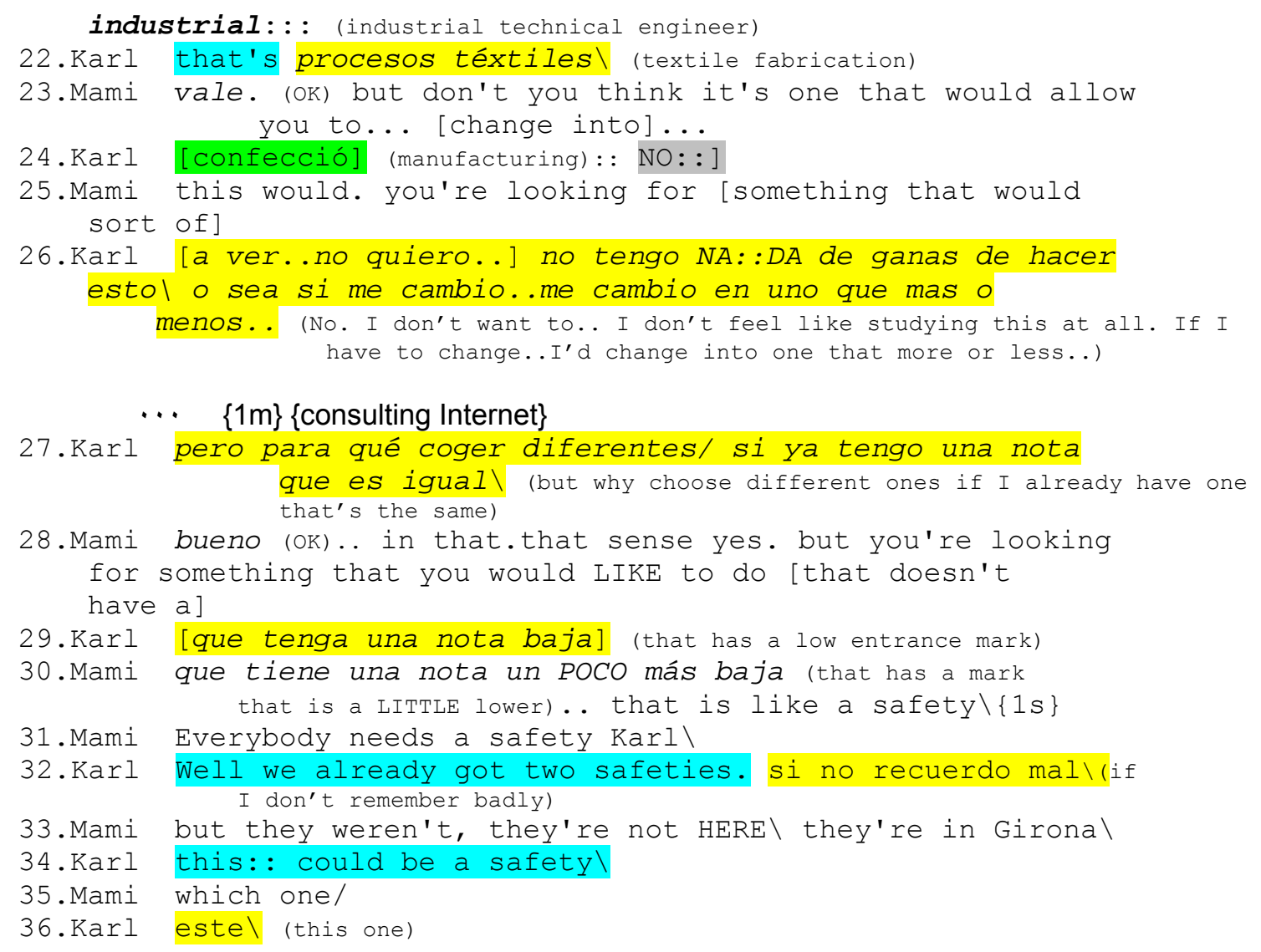

In this dialogue, Karl employs Spanish (81\%) to a great deal more than English (13\%) (Table 3). Given that Karl's preferred language choice with his mother is English (see Table 2), we must examine what internal psychological issues or external contextrelated issues are affecting Karl's language expression in this sequence.

As regards context, all of the information that Karl and his mother are consulting is in Catalan and the use of this language by Karl is associated with reading the names of programs (turn 5) or classes (turn13) from the computer screen in short interventions. Catalan and Spanish have much more in common with each other than either do with English, and the fact that the consulted information is in Catalan could influence the language choice of the participants, putting Karl into a 'Spanish' mind-set.

Context aside, there is also a clear discursive voice throughout most of this excerpt- that of 'complaint' or 'protest.' From this limited data set, it would appear that Karl's discursive voice of 'complaint' directed towards his mother is expressed in Spanish. Possibly, Karl is establishing distance between himself and his mother by employing her non-dominant language. The language choice serves to reinforce the declarative meaning of the lexis, bringing more weight to Karl's protest. 
Between turns 27 and 36, language choice appears to be closely related to issues of intimacy and distance. Karl and his mother are discussing the need for finding a university program with a lower cut-off entrance mark, which they refer to as "a safety.” In turn 32, Karl states, “well we already got two safeties” in English, adding afterwards “si no me recuerdo mal” ('if I remember correctly’) in Spanish. In turn 34, Karl once again chooses to use English to say, “this could be a safety.” Turn 34 clearly marks a change in the tone of the conversation.. Karl finds a 'safety' that he believes could be acceptable and offers it up as a possible solution. His concession is expressed explicitly through his word choice and implicitly in his language choice. By employing the dominant language of his mother, he is reducing the tension created in their earlier disagreement. Interestingly, the semantic function of Karl's earlier turn "well we already got two safeties" is one of protest, not concession, while the language choice of this statement approximates intimacy with his mother. Karl appears to be attenuating his protest in this turn, drawing closer to his mother's position and preparing the groundwork for his concession in the following turn.

Karl's sister, Lisa, also appears to choose Spanish for her discursive 'complaint' voice with her mother. In the following sequence, Lisa and her mother are talking amicably in the kitchen as Lisa loads the dishes in the dishwasher. Lisa's mother interrupts the flow of the conversation to reprimand her daughter about how she is placing the dishes in the dishwasher.

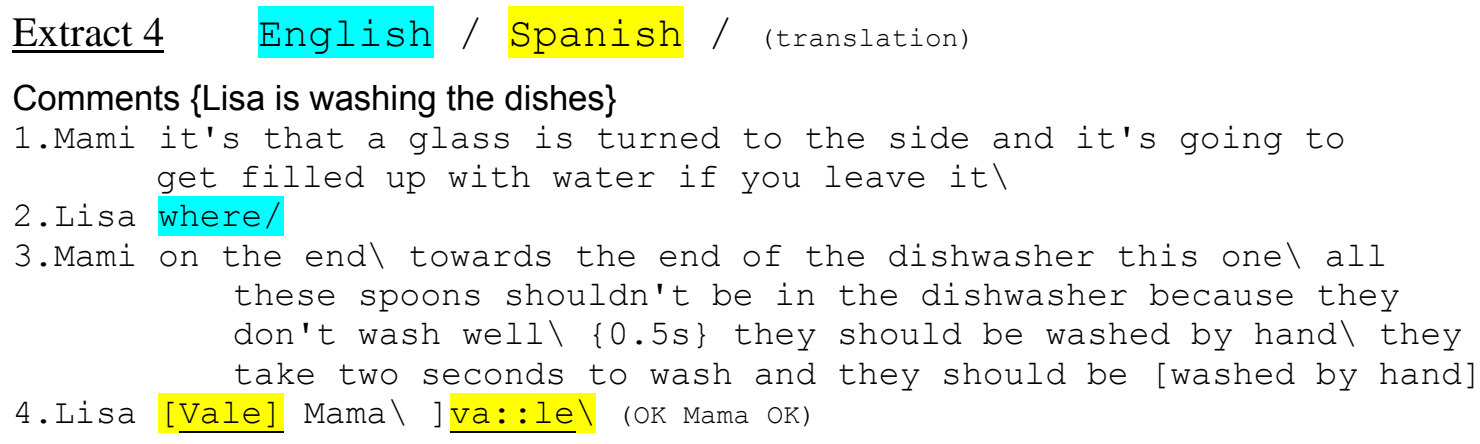

Lisa's mother has changed her footing from that of a comprehensive listener to that of a mother critical with her daughter's performance. Lisa, too, is forced to change footing and assume her role as a daughter being reprimanded by her mother. Lisa shows through the stress pattern, the repetition and her choice of language that she does not 
appreciate this interruption, though the surface meaning of her words "vale, vale” ('OK, OK') is one of acceptance.

Of course, one can argue that 'vale' is so incorporated into the bilingual language of Lisa and her mother, that her choice of language in this instance is merely incidental. A longer discursive 'complaint' voice pronounced by Lisa can be found in Extract 5. Lisa's mother tries to wrap up their conversation by rising from her chair to leave her daughter's room. When Lisa becomes aware of her mother's intention (turns13), she tries to convince her to stay (turn 4) and eventually questions her mother's perception of time (turns 6, 8, and 10).

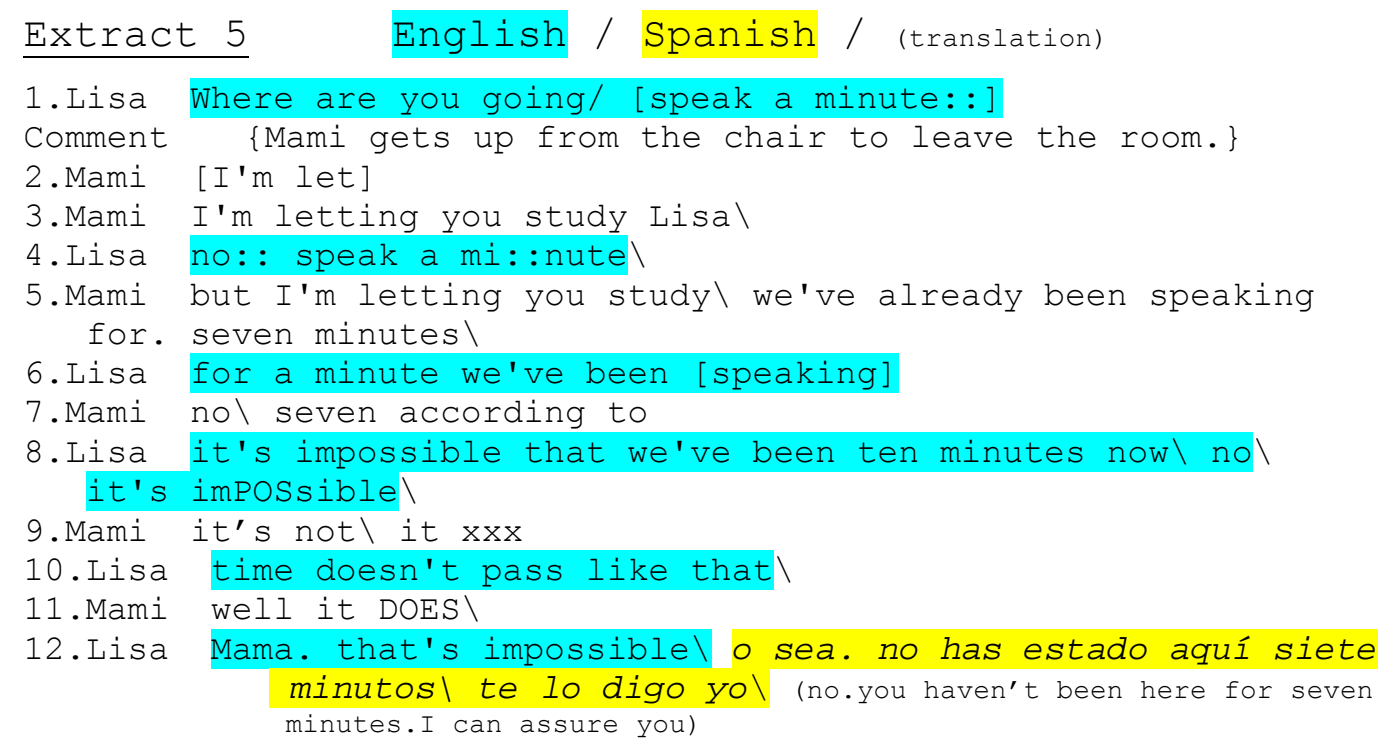

Although the entire sequence is carried out in English, Lisa switches into Spanish in turn 12. This turn consists of 4 utterances: in the first ("that's impossible”) Lisa repeats her words of turn 8; in the second, "o sea" functions as a discourse marker; and in the fourth, "te lo digo yo" functions as an emphatic device which, as we will see later, is used by Lisa in many examples of her speech with her mother. The third semantic utterance, "No has estado aquí siete minutes" is a statement of direct contradiction of her mother's previous statements in turns 5 and 8 . By formulating this complaint in the non-dominant language of her mother, Lisa takes a conversational step back, creating distance between her mother and herself by using both lexical and linguistic devices to express her nonconformance.

When Lisa wishes to complain about another person, however (Extract 6), she uses Spanish as a discourse marker (“que Laura”, “es que”) to set off the forthcoming 
English complaint or to emphasize her complaint (“jolín”). In other words, Lisa’s discursive voice of 'complaint,' manifested in this case by code-switching, cannot be characterized as her generalized complaint voice; rather, it is a 'personal-motherdirected complaint' voice, as is the 'mother-directed complaint' discourse voice of her brother.

Extract 6 English / Spanish / (translation) Lisa this afternoon. the little time I had to study $\{1$ s $\}$ first Ana
called one second $\{1$ s then Laura:
que Laura: : (it's that Laura) instead of sending an email she has to
call and then each time she calls it's like twenty minutes
$\{2 \mathrm{~s}\}$ you know/ ... es que (it's that) that's what I don't likel es que jolín.. (it's that I don't) I don't get distracted by my. by my own.. but people distract mel

Code-mixing and code-switching in the children's conversations with their mother: Extracts 7, 8 and 9

Lisa's use of terms such as 'jolín’ to add emphasis can be found throughout her interlocution with her mother. Lisa’s 'emphatic' voice in Spanish punctuates her very fluid baseline English, bringing an element of color into her speech and alerting her interlocutor that these words deserve special attention. Various factors combine to add special emphasis to the words Lisa chooses to highlight. These include the semantic sense of the lexis, their often end-of-utterance position, the stressed phonology with which they are pronounced and the code-switch itself. In Extract 7, Lisa remembers an especially annoying woman (“esa mujer pesada”) who bothered her younger brother on a beach in Florida. In Extract 8, Lisa explains how she wakes up completely (“de todo”) at a certain moment at night. Lastly, in Extract 9, Lisa uses the Spanish equivalent of 'I swear' in Spanish, to emphasize how much her friend can speak.

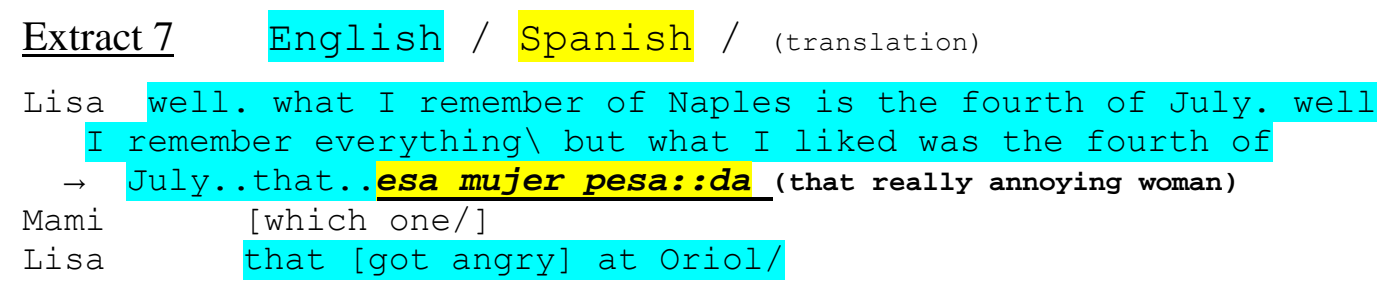

\section{$\underline{\text { Extract } 8}$}

Lisa is it for the thing you said/ es que (it's that)I don't know. I feel that. that there's a moment moment.. at twelve.for 
$\rightarrow$ example...that I wake up DEL TODO\(completely)

Extract 9

Lisa $\rightarrow$ but Ana when she wants to speak. she can speakl te ju: $\boldsymbol{\text { ro }} \backslash(\mathbf{I}$ swear) 
Code-mixing and code-switching in the children's conversations with their mother: Extracts 10 and 11

Code-mixing within a single lexical term can also serve to convey meaning beyond the declarative meaning of the lexis itself. In Sequence 10, Lisa and her mother are trying to engage Oriol in a conversation about a good piece of news that he has received at school. Oriol is aware that there is a recording device in the room and has decided that he does not want to respond to his sister's or his mother's requests for information.

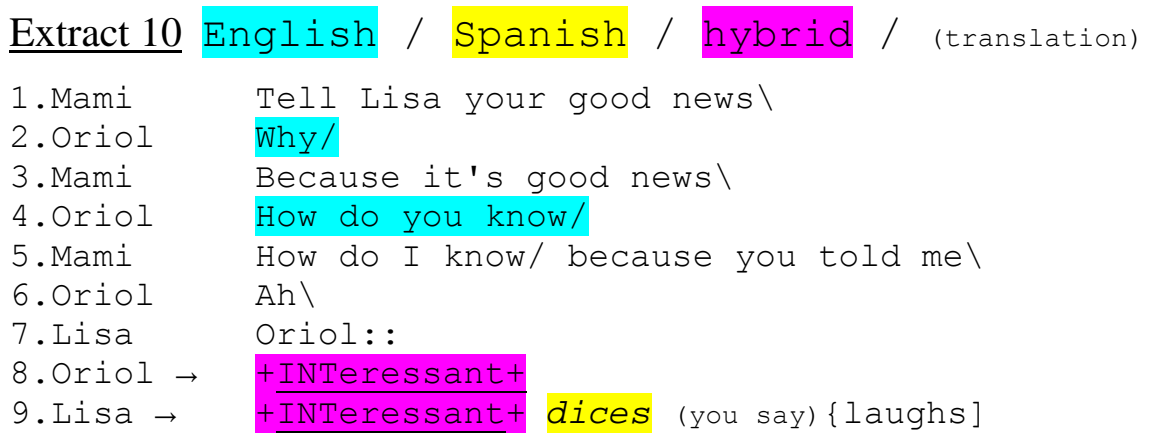

Oriol's code-mixing in turn 8 employs the English stress pattern and the Catalan suffix. The word "INTeressant" is used in a sarcastic, though humorous, form. Oriol transmits just the opposite of what the conventional meaning of his words state. This lexical invention does not go unnoticed by his sister who repeats it laughingly in the next turn. By code-mixing, Oriol converts this term into a non-offensive statement of disagreement.

The multicompetence in plurilingual families is found in combination with an enriched cultural knowledge about the home country of the first generation immigrant. In Extract 11, Lisa is talking with her mother about the custom on American college campuses to declare special days where all people must dress a certain way or carry out certain actions.

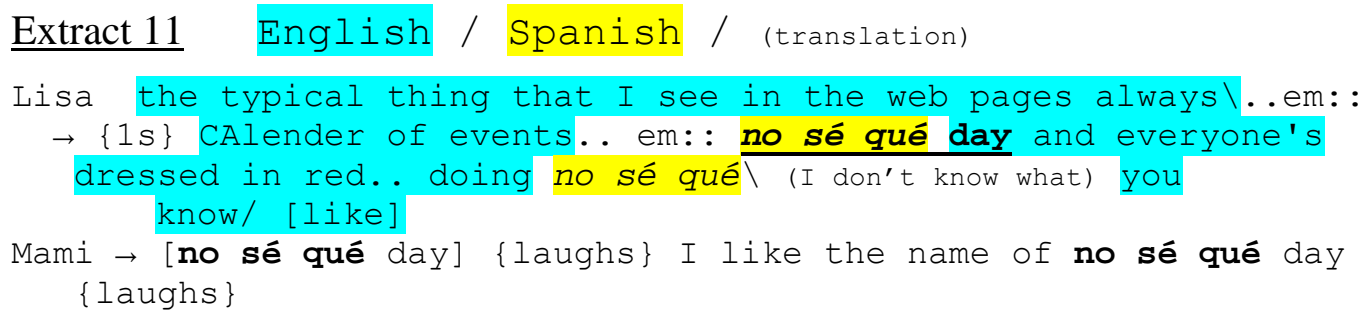


In this sequence, Lisa combines her cultural knowledge of the American college campus with her linguistic knowledge of both Spanish and English to invent a new term- 'No sé qué day.' The ability to coin this term brings into play three forms of knowledge: a cultural awareness of American customs and linguistic capacities in both Spanish and English. She combines her linguistic knowledge by placing the Spanish phrase 'no sé qué' in the position of an adjective modifying 'day.' It is impossible to know Lisa's precise motives in using these exact words or if she realized their lyrical potential (i.e. the rhyming pattern of 'sé,' 'qué and 'day') before pronouncing them. What we can confirm, nonetheless, is that her choice of words pleased her mother who repeats them twice laughing and specifically states that she likes the term.

\section{Conclusions}

This analysis, though limited in scope both in the extent of data collection and the object of study, reveals the complex form in which contextual factors and personal stances or viewpoints combine with a repertoire of multilingual resources to create a unique interactional environment between members of a plurilingual family. The family members use their multicompetence (Cook 1991, 2003) to speak plurilingually (Lüdi \& Py, 2009) and activate their entire repertoire of bilingual speech to negotiate meaning (Grosjean, 1985) between each other.

We have seen how code-switching is effectively used by the children to create intimacy or establish distance with their mother by respectively employing her dominant or non-dominant language. We have also seen how the children employ their multilinguistic register to formulate distinct discursive voices in the form of Lisa or Karl’s 'mother-directed-complaint' voice and Lisa’s ‘emphatic' voice.

The many examples of code-switching and code-mixing involving the naming of class subjects or academic concepts, together with Lisa's comment about the effort required to translate the names of subjects into English when speaking with her American grandfather, are demonstrations in support of Alvarez-Cáccamo’s (1998) claim that a distinction be made between the communicative and linguistic codes.

Lastly, we have seen how the combination of grammatical, linguistic and cultural knowledge permits the children to creatively express their opinions or ideas and 
even play with different languages. In this manner, inexistent terms are coined that are perfectly understood and appreciated by the conversational co-participants.

The coinage of terms for pragmatic purposes, as well as the situation-specific use of discourse voices cited above, supports Hall, Cheng and Carlson's (2006) claim for a user-based view of language knowledge in multicompetent speakers. This whimsical use of elements of distinct languages provides an excellent example of how multicompetent plurilingual speakers draw on all of their linguistic and cultural resources to enrich their speech in conversations with other equally plurilingual interlocutors.

Many questions still remain as to how multicompetence is activated and made manifest in plurilingual speech. Although translinguistic markers in the speech of plurilingual interlocutors are undoubtedly related at times to a lack of competence in the language system being employed, this article has shown how, in the majority of cases, code-switching and code-mixing are employed to facilitate and enrich the discourse of plurlingual speakers in a form unavailable to that of monolinguals, and, therefore, clearly argues in favor of the unique multicompetence of plurilingual individuals.

\section{References}

Alvarez-Cáccamo, C. (1998). Chapter 2. From 'switching code’ to 'code-switching': Towards a reconceptualisation of communicative codes. In P. Auer (Ed.), Codeswitching in conversation: Language, interaction, and identity (pp. 25-50). London: Routledge.

Alvarez-Cáccamo, C. (1990). Rethinking conversational code-switching: Codes, speech varieties and contextualization. In Proceedings of the Sixteenth Annual Meeting of the Berkeley Linguistics Society, February 16-19, 1990. General Session and Parasession on the Legacy of Grice (pp. 3-16). Berkeley: Berkeley Linguistics Society.

Auer, P. (1984). Bilingual conversation. Amsterdam: John Benjamins.

Auer, P. (1998). Introduction: Bilingual conversations revisited. In P. Auer (Ed.), Codeswitching in conversation: Language, interaction, and identity (pp. 1-24). London: Routledge.

Chromsky, N. (1965). Aspects of the theory of syntax. Cambridge, MA: MIT Press.

Cook, V.J. (1991). The poverty-of-the-stimulus argument and multicompetence. Second Language Research 7(2): 103-17.

Cook, V.J. (1999). Going beyond the native speaker in language teaching. TESOL Quarterly 33(2): 185-209.

Cook, V.J. (2003). The changing L1 in the L2 users mind. In V.J: Cook (Ed.), Effects of the Second Language on the First (pp.193-213). Clevedon: Mutilingual Matters.

Goffman, E. (1974). Frame analysis. New York: Harper \& Row. 
Goffman, E. (1981). Forms of talk. Philadelphia: University of Pennsylvania Press.

Grosjean, F. (1985). The bilingual as a competent but specific speaker-hearer. Journal of Multilingual and Muticultural Development, 6, 467-477.

Gumperz, J. (1982). Discourse Strategies. Cambridge: Cambridge University.

Hall, J.K., Cheng, A. \& Carlson, M. (2006). Reconceptualizing multicompetence as a theory of language knowledge. Applied Lingistics 27(2): 220-240.

Li, W. (2000). Dimensions of bilingualism. In W. Li (Ed.). The bilingualism reader (pp. 3-25). London: Routledge.

Lüdi, G. \& Py, B. (2009). To be or not to be... a plurilingual speaker. International Journal of Multilingualism. 6: 154-167.

Mondada, L. \& Pekarek Doehler, S. (2004). Second language acquisition as situated practice: Task accomplishment in the French second language classroom. The Modern Language Journal 88(iv): 501-518.

Myers-Scotton, C. (1997). Dueling languages: Grammatical structure in codeswiching. Oxford: Clarendon Press.

Selinker, L. (1972). Interlanguage. International Review of Applied Linguistics, 10, 209-241.

Unamuno, V. \& Nussbaum, L. (2006). La familia i l'entorn com a espais de transmissió de llengües. In L. Nussbaum \& V. Unamuno (Eds.). Usos i competències multilingües entre escolars d'origen immigrant (pp. 63-80). Bellatera: Serveis de Publicació de la Universitat Autònoma de Barcelona.

Weinreich, U. (1953). Languages in contact. The Hague: Mouton.

Woolard, K.A. (1988). Codeswitching and comedy in Catalonia. In M. Heller (Ed.), Codeswitching: Anthropological and sociolinguistic perspectives (pp. 53.76). Berlin: Mouton de Gruyter.

\section{Annex 1: Symbols of transcription}

\begin{tabular}{|c|c|}
\hline $\begin{array}{c}\begin{array}{c}\text { Description of the } \\
\text { phenomena }\end{array} \\
\end{array}$ & Symbols \\
\hline Ascendant tone & 1 \\
\hline Descendent tone & 1 \\
\hline Maintained tone & \\
\hline Small pause & (.) \\
\hline Medium pause & (..) more than half a second \\
\hline Long pause & $\left(n^{0}\right.$ of sec) \\
\hline $\begin{array}{l}\text { Syllabic lengthening } \\
\text { (according to the } \\
\text { duration }\end{array}$ & $::::::$ \\
\hline Simultaneous speech & [ texto] \\
\hline Interruption & text- \\
\hline Quite intensity & ${ }^{0}$ text $^{0}$ \\
\hline Loud intensity & TEXT \\
\hline Commentaries & $\{$ commentary\} \\
\hline Spanish & Italic type \\
\hline Catalan & Bold face type \\
\hline Phonetic transcription & + text+ \\
\hline Incomprehensible fragments & $\mathbf{X X X}$ \\
\hline Translations & (translation) \\
\hline
\end{tabular}




\begin{tabular}{|l|l|}
\hline English language code & English \\
\hline Spanish language code & Spanish \\
\hline Catalan language code & Catalan \\
\hline Uncertain language code & No \\
\hline Hybrid & Hybrid \\
\hline
\end{tabular}

\section{Author's References:}

Jill Simon Auerbach is a teacher in a public high school in the province of Barcelona. In addition to teaching English as a foreign language, she has also taught science classes in Catalan and in English due to her background as a Biochemistry major. For the past seven years, she has designed and run an extensive reading program for students of ESO and she has taught workshops on extensive reading in two editions of the Escola d'Estiu Rosa Sensat. Currently, she is a Masters candidate in the Department of Teaching Language, Literature and Social Sciences at the University Autònoma de Barcelona where she is specializing in CLIL (Content and Language Integrated Learning).

Email: jill.simon@e-campus.uab.cat

\section{Acknowledgements:}

I would like to thank the professors Dolors Masats and Luci Nussbaum in the Department of Teaching, Language, Literature and Social Sciences at the University Autònoma de Barcelona for their guidance and assistance in helping me to understand the many facets of plurilingual speech. I would also like to thank my children for allowing their casual conversations to be picked apart by their investigating mother. As always, they are a source of inspiration. This study has been funded by the MICINN (R+D+i EDU2010-15783 project). 